\title{
Kuidas keel ruumi loob? \\ Keelelise ruumiloome fenomenoloogia \\ kirjanduskogemuse näitel
}

TÕNU VIIK

See pole luule

see on maastik

mis ei lakka ilmumast

Cristina Chain, „Tahes-tahtmata”

(Lõunatuuled 2018: 49)

\section{Sissejuhatus. Keele ruumilised dimensioonid}

Kuidas on keel seotud ruumiga ja ruum keelega? Milline on keele ja ruumi vahekord? Üks võimalus on arvata, et keele mõisted on empiiriliselt eksisteerivate ruuminähtustega vastavusseoses. Kuid selline vastavusteooria ei selgita olukordi, kus teatud paigale, ruumile või maastikule omistatakse keele abil tähendusi (nt pühapaik, avalik ruum, looduskaitseala, kodumaa), nii et keeleline aktiivsus põhjustab muudatusi inimeste suhtumises ja käitumises ning viib selle kaudu ka ruumide endi teisenemiseni. Siingi on keele ja füüsikaliste ruuminähtuste vahel teatav vastavussuhe, kuid keel on aktiivsemas rollis kui lihtsalt reaalsuse peegeldaja - keelel on sellistel juhtudel ruumi kujundav funktsioon (vt Viik 2011). Keele ruumi kujundav jõud on kõige ilmsem, kui pöördume nende kohtade, ruumide ja maastike poole, mida on kujutatud ilukirjanduses. Enamasti peetakse neid ruume kujutluslikeks ehk fiktsionaalseteks. Nende eripära seisneb selles, et need eksisteerivad lugeva subjekti kogemuses, mitte objektiivselt. Füsikalistlikult mõistetud maailmas neil justkui kohta ei oleks, kogemuslikult aga eksisteerivad nad lugemise ajal justkui füüsilise maailmaga paralleelselt; kas eraldi dimensioonina reaalsuse sees või sellest väljaspool - mingisuguses eraldi olevas kirjanduslikus maailmas. Lugemisel tekkinud ruumitaju moodustab kõige ilmsema, otsesema ja võib-olla teoreetiliselt kõige provokatiivsema seose keele ja ruumi vahel. Siin keel sõna otseses mõttes loob ruumilisi dimensioone; kiri ja tekst tekitavad ruumilist ulatuvust.

Võtan järgnevalt vaatluse alla keelelise ruumiloome igapäevases keelekasutuses ja ilukirjanduse lugemise kogemuses. Ruumiloome on siin mõistetud osana lugemise kogemuses toimuvast tähendusloome protsessist (Viik jt 2018). Kasutan selleks fenomenoloogilist meetodit ja analüüsin konkreetseid näiteid argi- ja ilukirjandustekstidest, vaadeldes, milliseks kujuneb nende tekstide lugemise kogemus ja millised on selle kogemuse sisu ruumilised omadused. Valdav osa kirjanduskogemuse uurijatest on seisukohal, et lugedes me kujutleme tekstis kirjeldatut ning järelikult 
on lugemiskogemuse eelduseks ja läbiviimise „vahendiks” kujutlusvõime. Väidan, et kirjanduslike objektide ruumilised omadused ja tegevuspaigad ei ole kujutluslikud, vaid tekivad teadvusesse teistmoodi: ühe teistsuguse teadvusele omase võime rakendamise tulemusel, mida ma kutsun keeletajuks ehk keeleteadvuseks. Keeletaju on teadvuse toimimise viis, mis põhimõtteliselt eristub kujutlemisest. Lähtun selle eristuse ja keeleteadvusele omase tähendusloome viisi väljaselgitamisel Edmund Husserli märgi- ja kategoriaalse taju teooriast „Loogilistes uurimustes” (1900-1901).

Keskendun keelelise kogemuse analüüsimisel ilukirjanduslikele näidetele, millest poole valisin juhuslikult, aga teise poolde otsisin sihilikult poeetilisi tekste, mille sisu ning eelkõige ruumiline ja kohaloomeline tähendus oleksid meie loomulikus hoiakus toimiva argiteadvusega võimalikult suures vastuolus. Valitud luuletekstid ei kirjelda argiteadvusele tuttavaid esemeid, sündmusi, situatsioone ega tegelasi ning seetõttu on nende ruumilised omadused raskemini tabatavad kui realistlikus jutukirjanduses või argikõnes. Need on kõige raskemad ja väljakutsuvamad juhtumid selle jaoks, kes tahab kaitsta ideed, et ruumi- ja kohaloome meie keelelises teadvuses ei erine loomulikus hoiakus teadvuse empiirilisest ruumitajust mitte (kujutlusvõime abil loodud) sisuliste omaduste, vaid ruumiliste nähtuste keeleteadvusele omase „tühja” antuse viisi poolest meie keelelises kogemuses. Kui see on õige abstraktsete luuleridade puhul, siis on asi tõenäoliselt nii ka jutukirjanduse ja seda enam argise keelekasutuse puhul.

\section{Ruumiloome igapäevases keelekogemuses}

Vaatleme kõigepealt kogemuslikku ruumiloomet igapäevases keelekasutuses. Kui keegi ütleb: „Mari on kaugel”, siis võib seda lauset mõista kui väidet ühe Mari-nimelise inimese ruumilise paiknemise kohta. Me saame teada, et Mari on kohas, mis on ütleja asukohast eemal. Kui me asjast midagi rohkemat ei tea, siis määratleb neid kahte asukohta ainult nende vahele jääv distants, mis on ütleja hinnangul suhteliselt pikk; Mari on, nagu öeldud, lausujast kaugel. Kui seesama lause esineb kirjalikult, siis on lugejale samamoodi selge, et Mari on eemal. Pisut segasem on see, kellest või millest ta eemal on, siinsamas teda igatahes ei ole, ükskõik, mida siinsamas oleva all ka ei mõeldaks, olgu see mõni situatsioon, asi, koht või inimene. See tähendusseos on vastuolus lause enda ülesehitusega, kus Mari on lauseliikmena kohal, tema nime tähistav kiri on materiaalselt siinsamas (paberi või ekraani peal) olemas ja seetõttu lugejale empiiriliselt kogetav. Sama kehtib muidugi lausumisel tekkivate helilainete kohta: teatud helide jada kõlab kuulaja kõrvas Mari nimena ja on kuuldavana sel hetkel empiiriliselt presentne, samal ajal kui lause tähenduse järgi on Mari kaugel. Alles tähendusloome akt, mis saab teoks semioosi käigus - kui kellegi kogemuses saab öeldud või kirjutatud lause mõistetud -, paigutab Mari siinolevast eemale: kui empiirilises tähenduses, siis füüsilise vahemaa taha, kui allegoorilises või metafoorses tähenduses, siis vaimsele distantsile.

Kui ma ütlen, et „Mari on teises toas”, siis on tema asukoht juba konkreetsem nii iseloomu kui ka vahekorra poolest ütleja asupaigaga. Ja kui ma lisan, et toas, kus 
Mari viibib, on diivan, kirjutuslaud ja kaks tooli, saab Mari asukoht veelgi täpsema iseloomu. Sealjuures on Mari asukoht omadustelt palju rikkam, kui neis kahes lauses otse välja öeldud: me teame või vähemalt usume teadvat, et peale nimetatud mööbliesemete on toas tõenäoliselt ka aken, aga päris kindlasti on seal uks, lagi, seinad ja põrand; et põrand ja lagi on maapinnaga horisontaalsed ja seinad vertikaalsed; et seal on ilmselt ka laelamp ja ukse juures lüliti; et diivan on arvatavasti ühe või teise seina ääres, kuid vaevalt et seinal, laes, ukse ees või laua peal; ning et vähemalt üks toolidest on selline, millega saab istuda kirjutuslaua taga, ja et see küllap asetsebki kirjutuslaua taga. Me eeldame, et selle toa mõõtmed on vähemalt sellised, et inimene mahub püsti seisma ja liikuma; aga tuba ei ole ka jalgpallistaadioni suurune, sest me teame, et toad nii suured ei ole. Me eeldame, et tuba on osa hoonest, mille mõnes teises toas asub ütleja (vastasel juhul oleks öeldud: „Mari on teises majas”), ja et seda hoonet iseloomustab kõik see, mis hooneid tavaliselt: see ei lenda, vaid on paigal, selle on ehitanud inimesed, see asub planeedil Maa jne.

Me teame seda kõike sellepärast, et teame sõnade tähendusi ja oskame ette kujutada tüüpilisi tube, diivaneid ja kirjutuslaudu, tunneme nende funktsioone ja suhet teistesse asjadesse. Sõnade tähendused tulenevad nende kohast tähistajate võrgustikus, mis moodustab keele. Keelelise väljendi tähenduse määratleb ühelt poolt objekt või nähtus, millele see osutab, teiselt poolt suhe teiste keelemärkidega. Peale lausungite eksplitsiitsete tähendusseoste aktiveerivad keelendid semioosi käigus suure hulga implitsiitseid ehk konnotatiivseid tähendusseoseid, millest osa on ruumilised. Ruumilised on need selles mõttes, et osutavad ruumidele ja ruumilistele seostele, samuti asjadele, inimestele, nähtustele ja protsessidele, mis omavad ruumilisi mõõtmeid, asetsevad või toimuvad ühes või teises paigas, ning need paigad on omavahel ruumiliselt seotud.

Kui Mari on kirjanduslik tegelane ja me loeme lauset „Mari on teises toas, kus on diivan, kirjutuslaud ja kaks tooli” romaanist, siis ei muutu konnotatiivses tähendusloomes kuigi palju. Kui sõnaselgelt pole kirjas teisiti, siis jäävad selle ruumi omadused nii eksplitsiitsetes („teine tuba”, „diivan, kirjutuslaud ja kaks tooli”) kui ka implitsiitsetes tähendusseostes samaks nagu ülal kirjeldatud kõneaktis. Samasuguseks jääb ka vahemaa sellega, mis on „siin”. Ainus romaani lugemise kogemuse erinevus seisneb selles, et me ei eelda, et selliste omadustega ruum, kus Mari väidetavalt viibib, peaks reaalselt olemas olema, st empiirilises tegelikkuses eksisteerima, vaid et see ruum on fiktsionaalne - nagu Mari isegi. Kui aga Mari asemel oleks kirjandustekstis esineva lause aluseks Sokrates, siis juhul, kui me arvaksime, et jutt on Platoni dialoogide kangelasest, tuleks esile ajanihe lauses kujutatud tegevuse aja ja selle lause lugemise ajahetke vahel. Sõltuvalt meie ajalooteadmistest võiks meile hakata tunduma kummaline, et seal toas oli diivan, kirjutuslaud ja kaks tooli, ning me oleksime sunnitud korrigeerima mõningaid konnotatiivseid tähendusi - tõenäoliselt loobuksime eeldamast, et toas, kus Sokrates viibis, oli laelamp ja ukse juures selle lambi lüliti. Kuid sellele tähenduste konfliktile vaatamata kuuluksid meie lugemiskogemuse sisu juurde inimeste, asjade ja situatsioonide ruumilised omadused ja nende ruumiline paiknemine. Kuigi keele vahendusel kogetud ruumid on ebareaalsed, on nende ruumilised omadused sarnased vastavate objektide ja situatsioonide objektiivsete 
ruumiliste omadustega. Ilukirjanduslik Mari või Sokrates ja toad, kus nad võiksid viibida, on meie teadvuses samasuguse ruumilise ulatuvusega nagu reaalne Mari või Sokrates ja nende toad. Kui tekstis pole sõnaselgelt öeldud teisiti (nagu näiteks Jonathan Swifti „Gulliveri reisides”), tulevad keeleliselt kogetud asjade ruumilised määratlused ja mõõtmed reaalsuskogemusest keelelisse kogemusse kaasa.

\section{Kirjandusliku teksti lugemise kogemus fenomenoloogilises vaates}

Enamik autoreid, kes uurivad ilukirjandusliku teksti lugemise kogemust, keskenduvad asjaolule, et kirjanduslikud kujundid on fiktsionaalsed, st autor on need kujutlusvõimet rakendades välja mõelnud ja lugeja mõistab neid samuti kujutlusvõimet kasutades. Uurimisküsimus keskendub sellise lähenemise puhul kirjanduslike kujundite, ruumide ja sündmuse fiktsionaalsele iseloomule, autori kirjandusteoses leiduvate „väidete” teadlikule mittefaktilisusele ja sellest tulenevale lugeja hoiaku muutusele ning lugeja ja autori vahelisele „lepingule”, mis lubab lugejal kirjanduslikke väiteid mitte tõe pähe võtta. Hea ülevaate filosoofilistest fiktsiooniteooriatest annab Margit Sutropi artikkel „Mis on fiktsioon?” (1996), ülevaate fiktsionaalsuse mõistmisest läbi ajaloo võime leida Märt Väljataga kolmeosalisest artiklisarjast „Luule- ja pärislugude eristus teoorias ja praktikas" (2009). Sutrop juhib tähelepanu asjaolule, et ilukirjandusliku narratiivi puhul ei ole asi lihtsalt selles, et kirjandusteose sisu - tegelased, kohad ja sündmused - on välja mõeldud (kuigi see võib ka nii olla), vaid selles, et juba jutustaja ise on fiktiivne tegelane ja tema kirja pandud kõneaktid on fiktiivsed ehk kujutluslikud: „Fiktsionaalse narratiivi autor,” kirjutab Sutrop (1996: 303), ,[---] paneb kirja enda poolt välja mõeldud jutustaja kujutletud uskumusi." Seega on jutukirjandus kahekordne kujutlusakt: esiteks kujutleb autor rääkijat või kirjutajat, kes omakorda kujutleb seda, millest ta räg̈gib või kirjutab. Naiivne lugeja võib esimese kujutlusakti ära unustada ja jutustaja sedastatut autori isikliku seisukohana võtta. Mõnes kirjandustekstis võib aga jutustaja omakorda teisi jutustavaid tegelasi oma jutustusse haarata, ning sel juhul tekib kujutlemise tasemeid veelgi.

Oluline on märkida, et fiktsionaalsusteooriatest lähtudes on ilukirjanduse sisu loomine ja mõistmine eelkõige kujutlusvõime töö. Margit Sutrop võtab oma analüüsi kokku järgmiselt: „Kirjutades fiktsionaalset narratiivi, ei väljenda autor oma usku, vaid kujutlust. Fiktsioon on autori kujutlusakti väljendus." (Sutrop 1996: 303; vt ka Iser 2001) See tähendab, et me rakendame ilukirjandust luues ja lugedes ühte erilist teadvuse võimet - kujutlemist. Seda võimet rakendas kõigepealt autor, et väljamõeldud jutustaja kujutletud teksti kirjutada, ja nüüd peab seda rakendama lugeja, et teksti mõista.

Kujutlusvõime pidamine kirjandusliku kogemuse aluseks on uurijate hulgas valdav. Aga kas ilukirjandusliku lugemiskogemuse eeldus ja selle realiseerimise vahend on tõepoolest kujutlusvõime? Kas ilukirjanduses kujutatud objektide ruumilised omadused ja tegevuspaigad on tõepoolest kujutluslikud? Fantaasiakirjanduses loodud tegevuspaikade näited tunduvad seda seisukohta toetavat. Näiteks J. R. R. Tol- 
kieni teoste geograafiline tähendusloome sisendab, et paigad ja maa-alad, kus tegevus toimub, on kujutluslikud selles mõttes, et need ei ole füsikalistlikult reaalsed ja neid ei ole maakera pinnalt mõtet otsida. Need eksisteerivad autori ja lugeja tähendusloome aktides ning näivad olevat loodud ja tajutud kujutlusvõime abil. Kuigi nõustun, et ilukirjanduslikud paigad ei pruugi olla füsikalistlikult reaalsed ja et me oleme õppinud Keskmaa maastikke ette kujutama, ei ole ma kindel, et Keskmaa on kujutlusvõime vili. Me muidugi võime ja oskame seda visuaalselt ja kartograafiliselt ette kujutada ning sellest kujutluspilte luua, kuid ma arvan, et see maa-ala on meile lugemise kogemuses antud teisiti - ühe teistsuguse teadvuse võime abil, kui seda on kujutlemine. Lugemiskogemus võib kaasata ka kujutlusvõime, kuid väidan, et see põhineb ennekõike teadvuse registril või töörežiimil, mida võib kutsuda keeleliseks teadvuseks või keeleliseks tajuks.

Keelelist teadvust iseloomustab sellele iseloomulik, kujutlusvõimest erinev tähendusloome mehhanism. Märkasime juba, et sõnalise ruumiloome tähendussisu on argistel kõneaktidel ja kirjandustekstidel üsna sarnane. Kui eeltoodud näite juurde naasta, siis nii vahetu kommunikatsiooniakti kui ka ilukirjandusliku lugemisakti puhul esineb Mari meie kogemuses erilisel viisil topeldatuna: ühelt poolt ei ole võimalik teda empiiriliselt kogeda, sest ta ei ole „siin” ega viibi meie vaateväljas; ja teiselt poolt on ta "kohal” lauseliikmena, mida kuuldes või nähes (lugedes) saab kuulaja või lugeja teadlikuks inimesest, kelle nimi on Mari ja kes on määratletud (kui muud infot pole) ainult asukoha ja nime kaudu. Mari nime kirjapildil ega kõlal iseenesest eemal oleva Mariga mingit seost ei ole. Mari muutub nimena tähenduslikuks ja lause osutab eemal olevale Marile tähendusloome akti (semioosi) käigus lugeja või kuulaja teadvuses, aga seda ainult juhul, kui lugeja või kuulaja teadvus on keelelises hoiakus, st interpreteerib kirjamärkide või helikõlade tähendusi. See teadvuse hoiak või töörežiim on keeleline teadvus ehk keeleline taju. Teadlikkus isikust nimega Mari, kes on määratletud ainult nime ja eemalviibimise kaudu, on keelelise teadvuse saavutus, ning tema samaaegne kujutlemine (näiteks temast visuaalse kujutluspildi tekitamine) ei ole antud juhul otsustav. Otsustav ei ole ka see, kas Mari on fiktsionaalne tegelane või mitte. Teksti lugemine ja mõistmine, ka ilukirjanduse puhul, ei eelda tingimata, et me tekstiliselt loodud tähendusi tingimata kujutlema hakkaksime. Küll aga eeldab see keelelise tähendusloome võimet saada teadlikuks objektidest, millele keelelised väljendid osutavad.

Lähtun keeletaju mõiste sisustamisel Edmund Husserli „Loogiliste uurimuste” (Husserl 2009, edaspidi LU) esimeses uurimuses esitatud märgiteooriast ja kuuendas uurimuses esitatud kategoriaalse taju analüüsist. Husserl ise keeletaju ehk keeleteadvuse mõistet välja ei arenda, kuid ta loob eristuse semiootiliselt formeeritud tajuvõime, empiirilise taju ja kujutlusvõime vahel. Need eristused saavad järgnevas analüüsis määravaks. Keeleline taju ja kujutlusvõime võivad Husserli käsitluse järgi küll lugemiskogemuses teineteisega lõimuda, st ma võin lugemise ajal tekstis kirjeldatud asju ja olukordi endale ühtlasi ette kujutada, kuid tekstist aru saada või seda nautida saan ka ilma selleta. Kujutlemine võib, aga ei pea tingimata kaasnema teksti mõistmisega. 
Keeletajust saab Husserli fenomenoloogia kontekstis rääkida kui kirjaliku teksti või suulise kõne tähenduse tajumisest, mille käigus kuulaja või lugeja kogeb seda, millest tekst „räägib”. Husserl tuletab keeletaju iseloomu võrdlusest empiirilise tajuga. Ta märgib, et empiirilises tajus on kogemuse objekt alati antud 1) teatud perspektiivist vaadatuna, ühe oma külje poolt, 2) ajaliselt ühes hetkes või intervallis, ning 3) koos oma unikaalsete konkreetsete detailide ja omadustega, millest igaüks avaneb samuti ühest või teisest konkreetsest perspektiivist vaadatuna. Meelelist objekti pikemalt vaadeldes võib selle konkreetseid omadusi aina üksikasjalikumalt eristada, ning oma kogemust sellest objektist saab tähelepaneliku vaatluse abil lõputult rikastada. Keeletajus seevastu (olukorras, kus nimetatud objekti meie vaateväljas ei ole) on objekt meile antud ,justkui ühe hoobiga” olemuslikult ja terviklikult (LU VI: $₫ 8$, 570), mitte ühe külje pealt ega üldse mingist perspektiivist nähtuna. Ta on antud terviklikult, aga nii, et objekti detailidesse ja konkreetsetesse omadustesse ei ole võimalik süüvida, sest need kogemuses lihtsalt puuduvad. Husserli sõnul on siin tegemist „tühja tähendusintentsiooniga” (sks leere Bedeutungsintention) (LU I: $₫ 9,44$ ), ning selles seisnebki puhta keelelise kogemuse olulisim eripära: keeletaju objektid on antud "tühjalt", samal ajal kui empiirilise teadvuse objektid on alati antud vähemalt mingil määral "täidetult” ehk meelte abil konkretiseeritult. Nii näiteks jätab lause „Hoovis kasvab puu” tähenduse kogemine täiesti lahtiseks, milline see puu on, ega täpsusta ühtegi selle omadust, ükskõik kui pikalt ja tähelepanelikult me seda lauset ka ei vaatleks. Samal ajal on ükskõik kui põgus visuaalne kogemus samast puust alati rohkemal või vähemal määral ,täidetud” konkreetse empiirilise materjaliga, mis vaatajale tema asukohast nähtav on. See aga ei tähenda, et keeletaju haarab ainult üldistatud objekte ehk kategooriaid. Husserl kirjutab, et näiteks sõnaühend minu tindipott osutab lugeja jaoks empiiriliselt konkreetsele tindipotile, mis tema ees laual on, mitte tindipotile kui niisugusele või tindipottide üldisele tüübile (LU VI: $₫ 7,562)$.

Ka empiiriliselt konkreetsed objektid tulevad keeleteadvuses esile põhimõtteliselt tühjana kõigest sellest, mida nende kohal olemine empiirilise taju väljal võiks pakkuda. Need objektid tuuakse niisiis keeleteadvuses välja ühel erilisel, äraoleval kujul. Teiste sõnadega, keeleteadvus on äraolevate asjade tajumine kohalolutul viisil, nii et nad on esitatud tühjalt, ilma igasuguse konkreetse määratluse ja sisuta. Järgnev sõnaline kirjeldus võib keeleteadvuse objekte muidugi täpsemalt määratleda, kuid kirjeldatud piiride sees jäävad need keelelised täpsustused ikkagi tühjaks ja objekt ise kohalolutuks. Kui me just ei räägi asjadest, mida me samal ajal aistida saame, on keeletaju objektid ka koha-tud ja kohalolutud selles mõttes, et nad ei asetse üheski empiirilise maailma paigas ega saagi seetõttu meelelises kogemuses antud olla. Neil pole füsikalistlikult reaalset kohta ega ruumilist konteksti, nad on seetõttu põhimõtteliselt äraolevad ja meeleliselt kohalolutud, ning me tajume neid just sellisena.

Keelelise teadvuse või taju üks kõige silmatorkavam eripära muude teadvuse modaalsustega võrreldes seisnebki selles, et see annab võimaluse kogeda asju, mis meie empiirilise kogemuse väljas presentsed ei ole. Mõned neist ei ole aistitavad sellepärast, et nad on antud hetkel vaateulatusest väljas, aga on põhimõtteliselt vaadeldavad, teised aga sellepärast, et neid ei saagi kunagi empiiriliselt vaadelda. Esi- 
mest tüüpi nähtuste näiteks võib tuua planeedi Merkuur või Mari. Teist tüüpi nähtuste näiteks võib tuua sellesama Mari, juhul kui ta on kirjanduslik tegelane, aga ka sellised nähtused nagu õiglus, kuulsus või eestlus; ja tegelikult ka sellised asjad nagu loom, puu või pilvkate. Abstraktsete mõistete ja üldmõistete konkreetseid empiirilisi „kehastumisi” või „teostumisi” on võimalik empiiriliselt vaadelda, kuid mõisteid endid ega nende tähendusi mitte. Võime kohata konkreetseid puid või loomi, kuid mitte puud või looma kui niisugust. Keeleteadvus on ainus võimalus abstraktsetest ja üldistest mõistetest teadlik olla ja neid kogeda. Aga enamasti pole keelelise tunnetuse lähtepunktiks mitte sõna, vaid lause või pikem lausetest koosnev keeleline moodustis, ning me ei teadvusta mitte äraolevaid üksikobjekte, vaid asju ja nähtusi puudutavaid asjaolusid (Husserlil Sachverhalte). Seetõttu on süntaktiliste keelemoodustiste tähendus isegi empiiriliselt reaalsete objektide puhul pigem intelligiibne kui meeleline. Näiteks lause „See maja ehitati 1973. aastal” viitab küll meeleliselt vaadeldavale objektile, kuid väite sisu on kogetav ainult intellektuaalselt ja ainult keelelise teadvuse registris, Husserli termineid kasutades kategoriaalse taju (kategoriale Wahrnehmung) abil. (LU VI: § 45-46, 670-676)

Kujutlusvõime on midagi hoopis teistsugust. Ka siin suhestub teadvus äraoleva objektiga - see kujutlusvõime omadus sarnaneb keeleteadvusega. Kuid selle poolest, kuidas objekt antud on, sarnaneb kujutlemine empiirilise tajuga. Objekt avaneb ühe külje poolt vaadates, st perspektiivist, mida võib varieerida, kuid millest igal hetkel on aktualiseeritud vaid üks võimalus. Objekt on kujutlemise käigus antud koos oma konkreetsete omadustega, mis puudutavad selle kuju, osi ning osade ja terviku suhet. Empiirilise taju ja kujutlemise vaheline erinevus seisneb selles, et kujutlemise puhul on objekti konkreetsed omadused realiseeritud ettekujutuses, mitte empiiriliselt. Kujutlemise erinevus meelelisest tajust on ilmne, kui mõtleme näiteks olukorrale, kus me laua taga istudes kujutleme tiigrit, ja võrdleme seda olukorraga, kus meie pilgule avaneb seesama tiiger aistitaval kujul. Nii esimesel kui ka teisel juhul on ta antud teatud perspektiivist koos oma konkreetsete omadustega, kuid teadvusakti modaalsus on erinev: esimesel juhul on ta antud äraoleva ja kohalolutuna, teisel juhul empiiriliselt presentse ja siin-olevana. Seevastu puhta keeleteadvuse akti käigus ei ole objekti konkreetsed omadused üldse mitte mingil moel realiseeritud - me ei kujuta Husserli järgi sõna otseses tähenduses midagi ette, ehk teiste sõnadega: meie teadvuses ei pruugi tekkida üldse mingisugust visuaalset ettekujutust keeleteadvuse abil antud objektist. (LU VI: $\$ 21,607$ )

Võib muidugi küsida, kas kujutlemine tähendab alati pildilist ettekujutamist; kas ei eksisteeri mittevisuaalseid kujutlemise viise? Näiteks võib olla võimalik kujutleda mingeid helisid, hääli, lõhnu, maitseid või midagi kombitavat. Vastavad kujutlusvõime objektid peaksid sel juhul olema mitte mäletatud ega mõeldud, vaid just nimelt auditiivselt, olfaktoorselt, gustatoorselt või taktiilselt kogetud nende äraoleval ja kohalolutul kujul. Aga isegi kui niisugused kujutluse vormid on olemas, siis on need lugemiskogemuses sekundaarsed, sest kõigepealt on vaja keelelise taju abil teadlikuks saada sellest, milliseid häli või lõhnu võiks kujutlema hakata.

Samamoodi tuleb käsitleda ettepanekut pidada kujutlusvõimeks mõnda teist tüüpi mittevisuaalse teadvuse registrit. Näiteks võib väita, et ma rakendan oma 
kujutlusvõimet, kui tajun, et teatud inimesed on minu suhtes pahatahtlikud. Samuti võiksin „kujutleda” oma elu ühes või teises korteris, millest ühe üürimist või ostmist ma plaanin. Või siis võin „kujutleda”, mida ma teeksin, kui kõik teised inimesed maailmast ära kaoksid. Võin „kujutleda”, mis juhtuks, kui hommepäev töölt ära tuleksin, või milline inimene ma tegelikult tahaksin olla. Need on fantaseerimise, sisekaemuse ja intuitiivse mõtlemise vormid, mis tingimata ei visualiseeri oma objekte, vaid põhinevad keeleteadvusel ja intellektuaalsel intuitsioonil. Erinevalt visuaalselt, auditiivselt, olfaktoorselt, gustatoorselt või taktiilselt antud kujutluse objektidest mängib keel selliste teadvusaktide läbiviimisel olulist rolli, sest vastav kogemuse sisu vormub enamasti koos sisekõnega. Nii nagu pildilist ettekujutamist, võime ka neid teadvuse registreid lugemiskogemuse käigus ise aktiveerida, ning veel sagedamini aktiveeruvad neist mõningad meis tahtmatult.

Ma ei eita, et lugemise käigus tekitab tekst suure hulga sõnatuid muljeid, ettekujutusi ja muid reaktsioone; seejärel hakkame tajuma, mida me kirjeldatud nähtustest arvame; võime fantaseerida, kuidas me ise või kuidas keegi teine kirjeldatud asjaoludele reageeriks või neid hindaks; võime mõelda, mis jutustuses edasi saama hakkab või mida see kõik tähendab, mida autor meile öelda tahtis jne. Jätan siinkohal lahtiseks küsimuse, kas eksisteerivad eraldi heliline, lõhna-, maitse- ja kompimismeelega seotud kujutlusvõime, nagu ka küsimuse, kas teksti lugemise tagajärjel tekkinud muljeid ja reaktsioone ning tekstile rakendatud keeleliselt formeeritud intellektuaalset intuitsiooni ja fantaasiat peaks pidama kujutlusvõime üheks vormiks või mitte. Siinses kontekstis on vaid oluline märgata, et isegi kui seda sorti teadvusaktid lugemiskogemuses aktiveeruvad, siis põhinevad nad esmasel keeleteadvuse aktil, mille käigus me kõigepealt muutume teadlikuks sellest, mille kohta saame midagi kujutlema, fantaseerima või mõtlema hakata, seda samal ajal kas visuaalselt ette kujutades või mitte. Lugemissituatsioonis on keelelise teadvuse akt kõikide järgnevate teadvusaktide aluseks ja nende suhtes primaarne.

\section{Ruumilisus ilukirjandustekstis}

Ilukirjandusteksti kogemisel on peaaegu alati üks kindlapiiriline meeleline „sissejuhatus": raamatu võtmine riiulilt või lugeri avamine. Kuni ma seda teen, on ilukirjanduslik teos minu jaoks pelgalt empiiriline objekt. Alles raamatut avades ja lugemist alustades muutun teadlikuks millestki muust, kui ma otsekui sisenen teose kirjanduslikku maailma (vt Poulet 1969). Sama tegevuse käigus aktsepteerin „lepingu” autori ja lugeja vahel mitte võtta empiirilise tõe pähe seda, mis mu kogemise sisu kohe täitma hakkab. Minu teadvuse hoiak muutub selle ülemineku käigus argisest esteetiliseks (Ingarden 1961: 295).

Viisin läbi järgmise fenomenoloogilise eksperimendi, et oma arutlust lugemise kogemusest konkreetsete näidete abil kinnitada. Otsisin koduriiulist mõned raamatud, seades kriteeriumiks, et teos kuuluks eesti kirjanduse hulka ja oleks klassifitseeritav ,jutukirjanduseks" (vt Väljataga 2014: 108). Kaheksast avatud raamatust on neli niisugused, mille avalausetes kujutatakse otseselt ruumilisi vahekordi; tegevuse algus 
asetatakse maastikule, teatavasse kohta või ruumilisse olukorda, kas realistlikku või mitterealistlikku aegruumi:

(1) Pidurdasin bussipeatuse juures enne Kohtumaja, aga siis tundus mulle, et Jaanus seisab kaugemal. Vöötraja lähedal, helepruuni jope ja seljakotiga. Sõitsin natuke edasi, et ta sealt peale võtta [---]. (Kangro 2016: 9)

(2) Vastasmaja kolmandal korrusel elab üks mees, keda ma olen juba mõnda aega jälginud. (Kaus 2017: 7)

(3) Tillukese kadaka all aianurgas kulu ja sambla sees oli linnupesa. (Liiv 1954: 51)

(4) Järgmisel päeval oli poiss jälle kohal. (Undusk 1990: 7)

Autotee lõik Kohtumaja lähedal vöötraja juures, kellegi eluase vastasmaja kolmandal korrusel, aianurk linnupesaga ja „koht”, kuhu poiss järgneval päeval naasis, on autorite poolt teksti abil loodud kohad, millest lugu lugeja teadvuses alguse saab. Aga mõistagi võib lugu alata ka mõne muu, mitteruumilise kujundiga. Järgmise nelja teose avalausetes otsest kohaloomet ei esine ning ruumiloome on mõnel puhul väga piiratud ulatusega.

(5) TÕUSE ÜLES, ANDREAS, ÄRKA! Andreas kuuleb ema tuhmhella häält läbi une. (Veidemann 2018: 11)

(6) Ostsin enesele täna kaustiku. Küll oli ilus kaustik. (Kivirähk 2019: 7)

(7) Kui ma veel paks olin, siis hindasin üle kõige sisemist ilu. (Raud 2013: 7)

(8) Väike Illimar, kirjeldan sind nõnda, nagu mäletan minevikust ja nagu näen nüüd. (Tuglas 1970: 5)

Ema hääle kuulmine läbi une, kaustiku ostmise sündmus, minategelase endise seisukoha sedastamine ja pöördumine Illimari poole on seigad, mille tajumine ei nõua eksplitsiitselt fiktiivsete kohtade või ruumide loomist. Kuid esitatud sündmused, tegelased ja esemed ei ole ka mõeldavad ega kujutletavad ruumitutena, kolmemõõtmelist ulatuvust omamata, või aegruumi kuulumata. Nagu öeldud, tulevad keeleliselt kogetud asjade ruumilised määratlused ja mõõtmed loomuliku hoiaku reaalsuskogemusest keelelisse kogemusse kaasa. Kuigi me näidetes 5-8 nimetatud situatsioone ja asjaolusid empiiriliselt kogenud ei ole, on nende ruumilised omadused meie lugemiskogemuses samasugused nagu juhul, kui kogeksime neid empiiriliselt. Näites 6 nimetatud kaustik on meie lugemiskogemuses samasuguse kolmemõõtmelise ulatuvusega nagu reaalsed kaustikud, ning väike Illimar näitest 8 on tõenäoliselt nii suur nagu temavanused lapsed ikka. Näide 5 esitleb empiirilise objektina ema häält ja Andrease tegelaskuju. Häälel on antud näites ka kindlad ruumilised omadused: see kostab Andreaseni kusagilt mujalt, täpsemalt ema asukohast. Ja muidugi on näidetes toodud tegelaskujud kolmemõõtmelised nagu ka inimesed meie empiirilises tajus.

Valisin veel mõned raskemad näited luuletekstidest, sest erinevalt jutukirjandusest ei ole kohaloome neis iga kord ilmne ega isegi implitsiitne. Lüürika ei pruugi kujutada sündmusi, tegelasi ega esemeid nende ootuspärastes ruumilistes suhetes. 
Otsisin sihilikult tekste, mis ei fabuleeriks äratuntavaid sündmusi, situatsioone ega tegelikust maailmast tuttavaid asju ning kus ruumiline tähendusloome oleks seetõttu minimaalne või puuduks hoopis.

(9) Mälu pudeneb laiali / tolm täis kiiri ja / helinaid (Mihkelson 2016: 38)

(10) ma olen verinoor / ja südasüütu / jalgkiire käsitugev / ajuhull (Kangur 2015: 44)

(11) Ära mäleta mind. // Olin vaid unenägu, / sähvatus pärise põhjast. (Kareva 2019: 40)

(12) talvesüda / kui valguse kiirusega ei tõuse / ongi pime / pool neli (Kruusa 2017: 160)

(13) Tule, öö pimedus, / võta mind sülle. (Liiv 2016: 122)

(14) Siin puhkab? Ei ta puhka / midagi, lihtsalt möödas on, / läinud üle ja mitte ära. (Raud 2016: 85)

(15) küps keha, / läbi tulnud oma õunjast, ploomjast / kohumise, küpsemise, keemise ajast [---] (Pilv 2017: 47)

(16) Absoluutne päike. / Seista selles. (Õnnepalu 2012: 87)

(17) Uusim teaduslik fantastika / Kapten Granditaotlus (Luks 2013: 26)

(18) selgub sedavõrd / kui selge oled (Soomets 2015: 10)

Neid tekste moodustav tähistajate võrgustik osutab asjadele ja seikadele, mis ei ole argiteadvusega kooskõlas. Kui proosateadvuses (st jutukirjanduse lugemise kogemuses) oleme harjunud osutatud mõistete tähendusi seostama sõnadega samasugusel moel nagu loomulikus hoiakus kogetud asjade tähendusi argiteadvuses, siis luuleteadvuses see ootus ei kehti. Harjumuspäratult nimetatud ja ebatavalisel viisil keeleliselt seostatud asjad ja nähtused nihestavad meie argist ja proosalist keeleteadvust ja selle loomulikule hoiakule iseloomulikku normatiivsust. Luuletekstid seovad asju ja nähtusi mõnikord ebamäärasteks, sageli harjumuspäratutena mõjuvateks kooslusteks.

Vaatleme täpsemalt, mida me nende tekstide lugemisel endale ikkagi teadvustame või ette kujutame. Kas tõesti loome näidet 9 lugedes kujutluspildi sellest, kuidas mälu laiali pudeneb, või kuidas keegi absoluutses päikeses seista sooviks (16), või ettekujutuse sellest, milline on näites 15 esitatud „küps keha”? Seda enam, et enamik tekste $(10,11,12,13,14,17,18)$ ei kujuta otseselt midagi ega kutsu meid öeldut oma kujutluses visualiseerima, vaid justkui väidaks midagi, edastaks mingi seisukoha või võrdpildi.

Proovime tähele panna, mis moodustab meie teadvuse sisu neid tekste (näited 9-18) lugedes; mida me täpsemalt neid tekste lugedes kogeme. Mingisugune kogemussisu teadvuses kindlasti tekib, kui me keelt valdame ja oleme teadlikud luuležanrist. Selles veendumiseks võime lugeda järgmist kahte luulena esitatud rida:

(19) kollaseid laba vajuvad ust / kuiv neiks ei lumme

(20) läint esk vüül / ragii er num / vaik arr 
Need kaks teksti ei võimalda meil mitte mingisuguseid tähendusseoseid kogeda selles mõttes, et nende lugemisel ei teki isegi mitte ühte või teist normatiivsust nihestavat arusaama sellest, millele sõnakombinatsioonid näites 19 või tähekombinatsioonid näites 20 võiksid osutada. Teadvus ei liigu teksti tasandilt asjade ja sündmuste tasandile, kus leiab aset see, millest tekst räägib, vaid jääb sõnade (näide 19) või isegi tähtede (20) tasandile kinni. Seevastu juhul kui teksti autor järgib süntaksi ja loogika reegleid, moodustavad sõnad tähistajate võrgustiku või koe, mille seosed panevad lugeja teadvuse tööle, nii et sellest moodustub keelelise kogemuse keeleväline sisu. Me liigume tekstitasandilt järgmistele, mittetekstilistele tasanditele. Näidetes 19 ja 20 seda üleminekut ei teki, sest süntaksivaba sõnakasutuse (ja teisel juhul tähekasutuse) viis ei moodusta tähistajate võrgustikku, mis omandaks keelelise tähenduse. Me kogeme neid tekste visuaalselt, võime sisse lülitada oma teoretiseerimis- või kujutlusvõime ja argumenteerida, et need midagi tähendavad, aga puhtas keeleteadvuse registris ei tähenda nad siiski midagi.

Keeleteadvus võimaldab lugeja teadvuses kogemussisu moodustumist ainult juhul, kui tähemärke kasutatakse sõnade moodustamiseks ning sõnu pannakse ritta loogika ja süntaksi reegleid järgides. Vastasel juhul keelelise tähistamise funktsioon katkeb ja keelevälist kogemussisu ega vastavaid objekte lihtsalt ei moodustu. Tekst ei viita enam millelegi peale iseenda ning õigupoolest lakkab olemast tekst. Tekst on keelelises teadvuses alati midagi enamat kui kiri, ning see teadvuse sisu avardumine saavutatakse tänu süntaksireeglitele ja nende mõistmise oskusele. Kirjandusliku kogemuse tekkimiseks on peale keele- ja loogikareeglite vajalik väga paljude sõnastusreeglite (sh žanrireeglite) järgimine, ning see kehtib seda enam, kui mõningaid neist reegleist kunstipäraselt rikutakse.

Nüüd kui me oleme kindlaks teinud, et näited 9-18 siiski millelegi osutavad ja seetõttu erinevalt ridadest 19 ja 20 midagi tekstist väljaspool olevat kogeda võimaldavad, peame vaatlema, millised on selle kogemussisu ruumilised omadused. Võrreldes näidetega 1-4, aga ka näidetega 5-8, on neid luuletekste lugedes palju raskem ette kujutada kohti, kus tegevus (näide 9) või (potentsiaalne) sündmus $(13,16)$ aset võiks leida. Kus pudeneb mälu laiali (9), kus võtab öö pimedus autori sülle (13) või mis paik see on, kus ta tegelikult ei puhka, vaid on üle läinud (14)? Ülejäänud näidetes - kuna valisin ruumiloomet takistavad näited - ei juhtugi midagi niisugust, mis ruumi võtab või argiteadvuses mingi kohaga seotud on. Keegi lihtsalt ütleb midagi „enda” kohta $(7,10,11,16)$ või sedastab mingi mõtte mõne asja või nähtuse kohta endasse puutumatult $(12,14,15,17,18)$. Sellistel juhtudel ei toimu ka argielus ja loomulikus hoiakus oleva teadvuse kogemussisus eksplitsiitset ruumiloomet, kui välja arvata see, et ütleja ja ütlemise situatsioon on ruumiliselt määratletud. Nüüd aga nii ei ole. Vähestele nimetatud objektidele - mälu, talvesüda, küps keha, absoluutne päike - on raske nende abstraktsuse astme ja ebatavalisuse tõttu argiseid ruumilisi dimensioone omistada.

Ent mingi minimaalne ruumiloome siin siiski toimub, st luuleridadest 9-18 tekkinud tähendussisud ei ole päris ilma ruumiliste omadusteta. Nimetatud objektid, tegevused ja potentsiaalsed situatsioonid on muude omaduste kõrval ka ruumiliste mõõtmetega. Laiali pudenev mälu, talvesüda, küps keha, absoluutne päike on ruu- 
miliselt ebamäärased, kuid mitte ilma ruumilise ulatuvuse ja kohata. Enda kohta lausutu või millegi muu kohta sedastatu on küll lahti seotud reaalsest ütlemise kohast, kuid ütleja mina on (erinevalt näiteks kõikjal viibivast omnipotentsest jumalast) siiski ruumiliselt lokaalne. Isegi näide 18 keskendub kellelegi konkreetsele, lihtsalt me ei tea, kes see on. Ka sedastused näidetes 12, 14, 15, 17 ja 18 siiski piiritlevad selle, mille kohta nad midagi väidavad, ning piiritletus on millestki teadlikuks saamise üks eeldusi. Iga piiritlemine pole mõistagi ruumiline, näiteks erinevus arvu $100 \mathrm{ja}$ 101 vahel on kontseptuaalne ning tõenäoliselt ilma igasuguse ruumilise ulatuvuseta meie teadvuses. Kuid isegi sellised nähtused nagu kiire pimenemine talvel (12) või iroonia granditaotluste teemal (17) rägigivad nähtustest, mida kogetakse ruumiliselt lokaalsetena.

Võime õigustatult tõstatada küsimuse, kuidas suhestuvad need lugeja kogemuses tekkinud ruumilised moodustised ja asjade ruumilised omadused füsikalistlikus mõttes reaalse ruumi ja seda täitvate asjadega, ning vastata, et need on fiktsionaalsed ehk kujutluslikud ning selles mõttes ebareaalsed. Samal ajal nägime, et need ruumilised moodustised on samasuguste või vähemalt väga sarnaste ruumiliste omadustega nagu empiiriliselt reaalsed objektid meie meelelises tajus. Kirjanduslike ja reaalsete objektide ruumilisus on samasugune või vähemasti väga sarnane. Pealegi ei ole õige taandada lugemiskogemuse sisu kujundavat teadvuserežiimi kujutlusvõimele. Seetõttu ei ole kujutlusvõime ja meelelise taju vastandusest võimalik tuletada kirjandusliku ruumiloome eripära. Kirjanduslikud ruumid ja kirjanduslik ruumilisus ei ole teistsugused kui meelelised ruumid ja ruumilisuse iseloom argises hoiakus, samal ajal kui näiteks neljamõõtmeline matemaatiline ruum on argisest ja kirjanduslikust ruumist vägagi erinev. Järelikult ei ole antud kontekstis kuigi sisukas ütelda, et kirjanduslik ruumiloome on fiktsionaalne, sest esiteks ei saa väita, et tegu oleks mingit ebaharilikku tüüpi ruumilisusega, ja teiseks ei ole kirjanduslik ruumilisus oma esmases antuse vormis kujutluslik. Me vajame kõigepealt keeleteadvuse tekitatud ruumi teadvuses, et võiksime seda hakata kas ette kujutama, mõtestama või mingisugusel muul viisil täiendavalt ja rikastavamalt tajuma, kui see esmalt keeleteadvuses antud on.

Nagu nägime, on keeleteadvuses esitatud asjade ja asjaolude ruumilised omadused ja mõõtmed kogetud „tühjalt” - nii nagu asjad isegi. Kui ma avan Jan Kausi romaani ja loen, et „Vastasmaja kolmandal korrusel elab üks mees, keda ma olen juba mõnda aega jälginud", siis ei asu ma kujutlema, milline maja see on, mida Kaus või tema romaani jutustaja täpsemalt silmas peab. Ma jätan selle lause lugemisel maja võimalikud empiirilised variandid lahtiseks - minu teadvus ei loo täpsustavaid kujutluspilte sellest, kas see on eelmise sajandi alguses ehitatud puitmaja, nii nagu neid võib näha Kadriorus ja Kalamajas, nõukaaegne või päris nüüdisaegne paneelmaja. Tõsi küll, ma tean, et sellel majal on vähemalt kolm korrust, mistõttu mõned majade tüübid välistuvad. Samuti ei juurdle ma selle üle, miks Kaus või tema jutustaja sellise maja mängu tõi, kuigi võiksin seda tahtmise korral teha, aga selleks pean ma oma teadvuse registrit vahetama ja lugemise režiimist väljuma. Samamoodi võib juhtuda, et loetu mõjutab mind nii tugevalt, et tahtmatu ja kontrollimatu reaktsioon loetule sunnib mind lugemise režiimist väljuma. Sellisel juhul tekst justkui lennutab 
mu teise seisundisse, et loetut emotsionaalselt tajuda, hinnata või mõtestada. Aga puhtas lugemise registris saan lihtsalt lauses öeldust aru ja muutun teadlikuks sellest, millele lause osutas. Sellele ei järgne enamasti mitte lause objekti kujutlemine ega selle mõtestamine, vaid lugemisega edasi minek, järgmise lause lugemine. Neljandat lauset lugedes saan teada, et jutustaja näeb meest aeg-ajalt rõdul, kus ta käib suitsu tegemas. Ma modifitseerin oma keeleteadvuses loodud „vastasmaja” niisuguseks, et sellel on „rõdu”. Enne neljanda lause lugemist ei olnud see maja minu keeleteadvuses ei rõduga ega rõduta, see oli vähemalt kolme korrusega „tühi” maja.

Ka teksti lugemisel tekkiv ruumiline suhe kahe maja vahel on ühelt poolt piiritletud ja teiselt poolt „tühi”. Minu lugemiskogemuses on ilmne, et jutustaja ja kirjeldatud mees elavad vastasmajades, sest jutustaja näeb meest tema rõdul suitsu tegemas. Raamatu esimesel leheküljel ma veel ei tea, kas see kahte maja siduv koht on romaani süžee jaoks oluline, kas jutustaja viib mu sinna veel tagasi, kas on pigem tegemist jutustajat ennast tutvustava asjaoluga või hoopis romaani žanri määratleva juhusliku kujundiga, mis annab lugejale teada, et ta peaks järgnevat käsitlema realismi võtmes. Need variandid jäävad minu jaoks raamatu esimesi ridu lugedes lahtiseks, kuid on oluline märgata, et ma võtan neid kahte teineteise vastas olevat maja konkreetselt: mulle on lugemiskogemuses antud just nimelt need majad, millest romaan räägib, ja mitte mõned teised, olgugi et „tühjalt”, ilma empiirilise, pildilise või kujutlusliku sisuta. Tühjalt antud kogemuse objekt on ikkagi just nimelt see konkreetne maja, mida jutustaja kirjeldab ja kus elab mees, keda ta rõdul suitsetamas näeb. Selle maja konkreetsus on mitteempiiriline ja tühi, aga sellegipoolest ei ole silmas peetud maja kui niisugust ega teatud majade tüüpi.

Me ei tea, kas need majad on tajutavas reaalsuses olemas või mitte, sest me ei tea, kas Kaus lähtus seda kirjanduslikku kujundit luues reaalselt eksisteerivast paigast nii nagu Kangro näites 1. Aga isegi Kangro näites on reaalne teelõik kõigest kirjeldatud teelõigu prototüüp teatud ajahetkel. Kirjanduslik kohakujund on reaalse koha suhtes primaarne, sest reaalse teelõigu ümberkujundamine ei muuda kirjanduslikku teelõiku, mis jääb igavesti selliseks, nagu Kangro seda kirjeldab. Kirjanduslikud kujundid jäävad meelelise maailma muutudes samaks; neid iseloomustab teistsugune temporaalsus kui empiiriliselt reaalse maailma objekte.

Küllap leidub reaalsuses palju kohti, mis sobiksid Kausi kirjeldatud kahe maja prototüübiks. Vajadus mõni niisugune koht leida tekiks näiteks siis, kui tahaksime romaanis kirjeldatud situatsiooni pildiliselt illustreerida, seda foto või filmiga edasi anda. Kui me sellised majad leiame, siis ei ole kirjanduslikud majad nende koopiad, vaid vastupidi. Seda loogilist sekundaarsust ei muuda isegi see, et psühhofüüsiliselt reaalse kirjaniku Kausi peas võis kirjanduslike majade loomisele eelneda visuaalne aisting või mälupilt just nimelt nendest majadest. Aistingu või mälupildi sisu võib olla psühholoogilises või empiirilises (näiteks neuroloogilises) mõttes autorile põhjuslikuks tõukeks kirjandusliku ruumi loomisel, kuid pärast kirjutamise akti on kahe maja „tühi” ruumilisus ikkagi kõikide selle meeleliste, kujutluslike või mälestuslike konkretiseeringute suhtes primaarne.

Samamoodi jäävad fotol või filmis kujutatud majad ikkagi ainult üheks võimalikuks visuaalseks illustratsiooniks majadele, millest romaan räägib (isegi juhul kui 
pildistatud või filmitud on neidsamu empiirilisi maju, mille kohta autor ütleb, et ta kirjutades just neid silmas pidas, ning on objektiivselt tõsi, et nende kahe maja aistimine tekitas tema teadvuses idee vastavast kirjanduslikust kujundist). Iga pildiline kujutis neist majadest visualiseerib neid kahte maja, millest Kausi romaan kirjutab ja mis meile romaani lugemisel „tühjalt” antud on. Kausi enda empiiriliselt reaalne aisting ei ole originaalile lähemal kui nende visualiseerimine pildikeeles kellegi teise poolt. Ning see, et erinevad pildilised konkretiseeringud räägivad ühtedest ja samadest majadest, on võimalik seetõttu, et need majad on esmalt meie keeleteadvuses „tühjalt” antud. Siin erineb ilukirjandus ajaloolisest kirjandusest, mille objektiks võib olla, ja sageli ongi, üks või teine reaalne ja konkreetne hoone. Ent kirjanduslike ruumide ja ruumiliste moodustiste aistingulised, pildilised või kujutluslikud konkretiseeringud on sekundaarsed selle suhtes, mida nad konkretiseerivad.

Tegelike prototüüpide puudumisel on see olukord iseenesestmõistetav. Lugeja kogemuses ei ole algselt midagi muud kui teksti poolt keelelises kogemuses tekkinud „tühjad” ruumid ja ruumilised moodustised. Autori kogemuses põhineb kirjandusliku kujundi loomine mõistagi teadvuse vool, mis sisaldab aistinguid, mõtteid ja kujutlusi, mis ajaliselt eelnevad kirjandusliku kujundi sõnastamisele ning millest mõned võivad olla loodava kujundiga kas autori enda arvates või ka tegelikult (neurofüsioloogilises mõttes) põhjuslikus seoses. Kuid autor teab väga hästi, et raamatut avades ja kirjanduslikku maailma sisenedes on esimene kujund just nimelt see, mida esimene lause ütleb, mitte see, mis moodustas tema teadvuse sisu selle kujundi loomise ajal. Professionaalne kirjanik on tõenäoliselt õppinud nägema oma loodud kirjanduslikke kujundeid lugeja perspektiivist, ning see tähendab, et nad on lahti seotud autori teadvuse voo sisust sel hetkel, kui tal selle kujundi idee tekib või see sõnastatud saab. Ning iga järgmine kujund põimub rangelt ainult kõigi seniste tekstis esinevate kujunditega vastavalt teksti loogikale, mitte autori teadvuse sisuga nende loomise eel või ajal.

Mõistagi kehtib see kõik ka ebarealistliku ja minimalistliku kohaloomega ilukirjandustekstide kohta. Näidetes 5-18 tajume minimaalselt järgmisi paiku, ruumilisi situatsioone või vahekordi:

a) ruumala, mille võtab enda alla mingi protsess, näiteks mälu laialipudenemine (9);

b) mingi koht, kus midagi toimub - näiteks see, kus Andreas ärkab (5), või see, kus „ta" ei puhka (14);

c) objektide ja isikute ruumilised dimensioonid: küps keha (15), absoluutne päike (16), kapten Granditaotlus (17), talvesüda (12), öö pimedus (13), ema ja Andreas (5), kaustik (6), väike Illimar (8);

d) jutustaja („tühi”) asukoht millegi väitmisel või soovimisel (5, 6, 7-14, 16, 18).

Kõik need kohad ja ruumilised situatsioonid on esmased oma aistinguliste, pildiliste, kujutluslike, afektiivsete või reflekteerivate konkretiseeringute suhtes. Nad on meile antud "tühjalt", ilma empiirilise ulatuvuseta, aga sealjuures on nad ikkagi konkreetsed - just nimelt need, millest tekstid jutustavad. Ükski vaadeldud tekstidest ei osuta asjade või kohtade üldtüübile, vaid konkreetsetele ruumidele ja 
objektidele. Isegi niisugused keeletaju objektid nagu mälu (9), talvesüda (12), küps keha (15) või absoluutne päike (16) osutuvad lähemal vaatlusel siiski konkreetseteks objektideks, kuigi on esitatud väheste või vastuoluliste joontega ja seetõttu raskesti ettekujutatavad. Selle joone poolest eristuvad ilukirjandustekstid ja igapäevane kõne teadustekstidest, mis sageli viitavad üldistustele endile, räägivadki asjade liikidest või tüüpidest kui niisugustest või nähtuste üldistest, mitte konkreetsetest omadustest. Igapäevases kõnes ja ilukirjanduses võib samuti ette tulla selliseid üldistusi, kuid enamasti lugeja tajub nende sisu ainukordse ja konkreetsena kas või juba seetõttu, et need on ühes või teises kindlas situatsioonis oleva jutustaja väited.

\section{Kokkuvõte}

Fenomenoloogilises vaates toimub kirjanduse lugemisel konkreetne ja samal ajal „tühi” tähendusloome, mis põhineb keeleteadvuse eripärasel toimimisel. Kogemuse objektid on lugemise käigus antud ühelt poolt justkui tüübile omase punktiirjoonega (nii nagu teoreetilises mõtlemises), mille saaks täita paljude konkreetsete omadustega (nii me seda näiteks illustreerimise ja visualiseerimise puhul teemegi), kuid ilukirjanduse lugemise kontekstis tähistab see punktiirjoon ka tühjaks jäädes siiski ühte konkreetset (kuigi mitte empiiriliselt konkreetset) objekti. Sama kehtib paikade, kohtade ja ruumide kohta. Kirjanduskogemuses avanevad konkreetsed objektid, situatsioonid ja nähtused, mis on ise ruumilised ja mis paiknevad või toimuvad kindlates kohtades, olles samal ajal rüütatud keele üldistesse tähistajatesse. Me kogeme kirjanduse lugemisel midagi konkreetset, mis on keeleloome iseloomu tõttu vahendatud üldise kaudu. See vahendatus ei tule lugemiskogemuses otseselt esile, kuid jätab teadvuse registrit vahetades võimaluse esitatud konkreetsetest asjadest ja kohtadest ka üldistatult (sh kriitiliselt) mõtelda või sõnadega esitatud konkreetsust kujutlusvõime abil „edasi arendada”, see fantaseerides mõne teise konkreetsusega asendada, näiteks lugejat ennast jutustaja või mõne tegelase positsiooni asetades või sellega vastandudes. Kõik need võimalused on avatud tänu keeleteadvuse akti esmasusele, mis loob võimaluse järgnevateks afektiivseteks, kujutlevateks või reflekteerivateks teadvuse aktideks ning nende kaudu teksti sisu tähendusloomelisteks täiendusteks ja edasiarendusteks.

Keeleteadvuse objektid, nende ruumilised omadused, situatsioonid ja paigad on konkreetsed ja unikaalsed, kuid erinevalt meeltega tajutud konkreetsetest objektidest ja paikadest ei ole nad lugemiskogemuses antud perspektiivselt, st nähtuna ühe oma külje poolt. Nad on teadvuses esitatud „tühjalt”, st ilma aistingulise, pildilise, kujutlusliku või reflekteeriva konkretiseeringuta, ning kõik sellised konkretiseeringud on nende suhtes sekundaarsed. Nende objektide ja paikade temporaalsus erineb empiiriliste objektide temporaalsusest selles mõttes, et kirjanduslikud objektid ja paigad ei muutu ajas, nii nagu empiirilised objektid ja paigad muutuvad. Nad korduvad lugemisel alati identsetena, st erinevad lugemisaktid elustavad täpselt neidsamu objekte ja paiku, mis tekstis kirjas on. Võib öelda, et kirjandusteost uuesti avades astume täpselt samasse jõkke nagu eelmisel korral. Meie sekundaarne kogemus 
sellest jõest võib mõistagi muutunud olla; me võime kirjandusteoses esitatule teisiti reageerida, sellest teisiti aru saada, seda teisiti hinnata ja väärtustada, kuid me mõistame ja hindame täpselt neidsamu keeleteadvuses antud kirjanduslikke kujundeid, mida me eelmistelgi lugemiskordadel keeleliselt tajusime.

Artikli valmimist on toetanud projektid "Maastikuline lähenemine rurbaansusele" (PRG 398) ja "Minu tulevikukolleeg robot" (TÕA20075).

\section{KIRJANDUS}

Husserl, Edmund 2009. Logische Untersuchungen [1900-1901; nach Husserliana XVIII, 1975 und XIX/1-2, 1984]. Toim Elisabeth Ströker. Hamburg: Felix Meiner.

Ingarden, Roman 1961. Aesthetic experience and aesthetic object. - Philosophy and Phenomenological Research, kd 21, nr 3, lk 289-313.

Iser, Wolfgang 2001. Das Fiktive und das Imaginäre: Perspektiven literarischer Anthropologie. Frankfurt am Main: Suhrkamp.

Kangro, Maarja 2016. Klaaslaps. Tallinn: Nähtamatu Ahv.

Kangur, Mart 2015. Kõrgusekartus. Tallinn: Kirimiri.

Kareva, Doris 2019. Suik ja sillerdus. Tallinn: Verb.

Kaus, Jan 2017. Kompass. Miniatuurromaan. Tallinn: Hea Lugu.

Kivirähk, Andrus 2019. Sinine sarvedega loom. Tallinn: EKSA.

Kruusa, Kalju 2017. Ühe inimese elu (pooleli). Tallinn: Kirimiri.

Liiv, Juhan 1954. Teosed. Koost Aarne Vinkel. Tallinn: Eesti Riiklik Kirjastus.

Liiv, Juhan 2016. Lumi tuiskab, mina laulan. Valik luulet. Koost Jüri Talvet. Tallinn: Tänapäev. Luks, Leo 2013. 100\% Leo Luks. Saarde-Pärnu: Ji.

Lõunatuuled. Tšiili luule II. Koost Marcelo Gatica Bravo. Tlk Mariliin Vassenin. Tallinn: M. G. Bravo, 2018.

Mihkelson, Ene 2016. Kõik redelid on tagurpidi. Tallinn: Eesti Keele Sihtasutus.

Pilv, Aare 2017. Kui vihm saab läbi. Mälestusi ühest ajastust (2007-2015). Tallinn: Tuum.

Poulet, Georges 1969. Phenomenology of Reading. - New Literary History, kd 1, nr 1, lk $53-68$.

Raud, Rein 2013. Vanem Paksem Tigedam. Tallinn: Mustvalge.

Raud, Rein 2016. Unelindude rasked saapad. Tallinn: Näo Kirik.

Soomets, Triin 2015. Hulgakesed. Tallinn: Verb.

Sutrop, Margit 1996. Mis on fiktsioon? - Akadeemia, nr 2, lk 292-305.

Tuglas, Friedebert 1970. Väike Illimar. Tallinn: Eesti Raamat.

Undusk, Jaan 1990. Kuum. Lugu noorest armastusest. Tallinn: Eesti Raamat.

Veidemann, Rein 2018. Piimaring. Romaan. Tallinn: EKSA.

Viik, Tõnu 2011. Human spatiality: A cultural phenomenology of landscapes and places. Problemos, kd 79, lk 103-114.

Viik, Tõnu; Torop, Peeter; Raudsepp, Maaris 2018. Kultuurisõltelise tähendusloome teoreetilised mudelid. - Acta Semiotica Estica, kd 15, lk 32-63.

Väljataga, Märt 2009. Luule- ja pärislugude eristus teoorias ja praktikas. - Keel ja Kirjandus, nr 6, lk 401-411; nr 7, lk 505-526; nr 11, lk 818-829. 
Väljataga, Märt 2014. Kirjandus ja selle liigid. Gümnaasiumiõpik. Tallinn: Maurus. Õnnepalu, Tõnu 2012. Kuidas on elada. Tallinn: Varrak.

Tõnu Viik (snd 1968), PhD, Tallinna Ülikooli humanitaarteaduste instituudi filosoofia professor (Narva mnt 29, 10120 Tallinn), tonu.viik@tlu.ee

\section{Linguistic spatiality: phenomenology of space-formation in speech and literature}

Keywords: phenomenology, linguistic experience, reading experience, fiction, spatiality

The paper takes a phenomenological approach and looks into spatial formations (such as a room, a territory, a landscape, a city, a country) that are indicated in conversation and texts of literary fiction. As an example of such spatial formations we can think of the "Middle-earth" in The Lord of the Rings, but also of almost any spatially situated object or action that is conveyed to us by using words. Most of the research into the readers' experience of fiction holds the view that these spaces are imaginary, i.e. they are a product of the writer's imagination that is conveyed to the reader's imagination by means of reading. Based on Husserl's theory of signs and categorial intuition in the Logical Investigations I argue, in contrast, that imagination is not required to elucidate the readers' experience of conversational or fictional spaces. The paper maintains that human linguistic consciousness is capable of intending the spatial formations "emptily", "unfulfilled by", or devoid of any imaginary or perceptual details. Thus the spatial formations of literary fiction are not imagined, but linguistically intended. Linguistic experience (of reading fiction, for example) has a way of constituting its objects that is irreducible to imagination. A number of examples from the Estonian literature are analyzed to prove and illustrate this process. The spatial formations that are created in reading these texts are numerically singular and unique, but unlike the singular objects of empirical perception or imagination they are not given (in the course of the experience of reading) in a perspective, they are without any particular details regarding their visual aspects or characteristics, and their temporality differs substantially from the objects of imagination and perception; they do not change in time and are characterized by "infinite repeatability".

Tõnu Viik (b. 1968), PhD, Tallinn University, School of Humanities, Professor of Philosophy (Narva mnt 29, 10120 Tallinn), tonu.viik@tlu.ee 